\title{
BRACHIOPODS OF THE SUBFAMILY ATELELASMATINAE (CLITAMBONITACEA) FROM THE ARENIG, ORDOVICIAN, OF THE BALTIC KLINT AREA
}

\author{
Madis RUBEL a and Leonid POPOV ${ }^{b}$ \\ a Eesti Teaduste Akadeemia Geoloogia Instituut (Institute of Geology, Estonian Acad- \\ emy of Sciences), Estonia pst. 7, EE-0100 Tallinn, Eesti (Estonia) \\ b Всероссийский геологический институт (All-Russian Geological Institute), Средний пр. \\ 74, 199026 Санкт-Петербург, Россия (Russia)
}

Presented by D. Kaljo

Received April 26, 1994; accepted May 20, 1994

\begin{abstract}
Four weakly-known species of the genera Apomatella and Neumania of the subfamily Atelelasmatinae are described from the Arenig of the Baltic klint area. The diagnoses of both genera are emended. The distribution of these oldest clitambonitid brachiopods of the area is discussed.
\end{abstract}

Key words: clitambonitid brachiopods, species description, Ordovician, Estonia, Russia.

\section{INTRODUCTION}

For a long time the species Apomatella ingrica (Pahlen) was known as the single representative of the subfamily Atelelasmatinae from the Arenig of the East Baltic (Opik, 1934). The more recent collections by Ralf Männil and Linda Hints of 1956, 1962, and 1964 and by Leonid Popov of 1975 and 1989 from the lower Ordovician of the Baltic klint indicate that now as many as four species of the subfamily occur in this area (Fig.). Two of these can be assigned to the genus Neumania described from the Upper Arenig of New World Island, Newfoundland (Neuman, 1976), and from the Early Ordovician Otta Conglomerate of south central Norway (Bruton \& Harper, 1981). These brachiopods can be identified with Pander's old species and have the following names: Neumania erecta and $N$. costata. Two other species, Apomatella ingrica itself and A. secunda, were previously known from the Arenig of the East Baltic and Norway, respectively (Opik, 1939).

The aim of this paper is to revise the morphology and taxonomy as well as the stratigraphic position of these species using the new collections. All the specimens figured here are kept in the Museum of the Institute of Geology, Estonian Academy of Sciences (Tallinn) under the numbers Br 911-919, 961-980. 


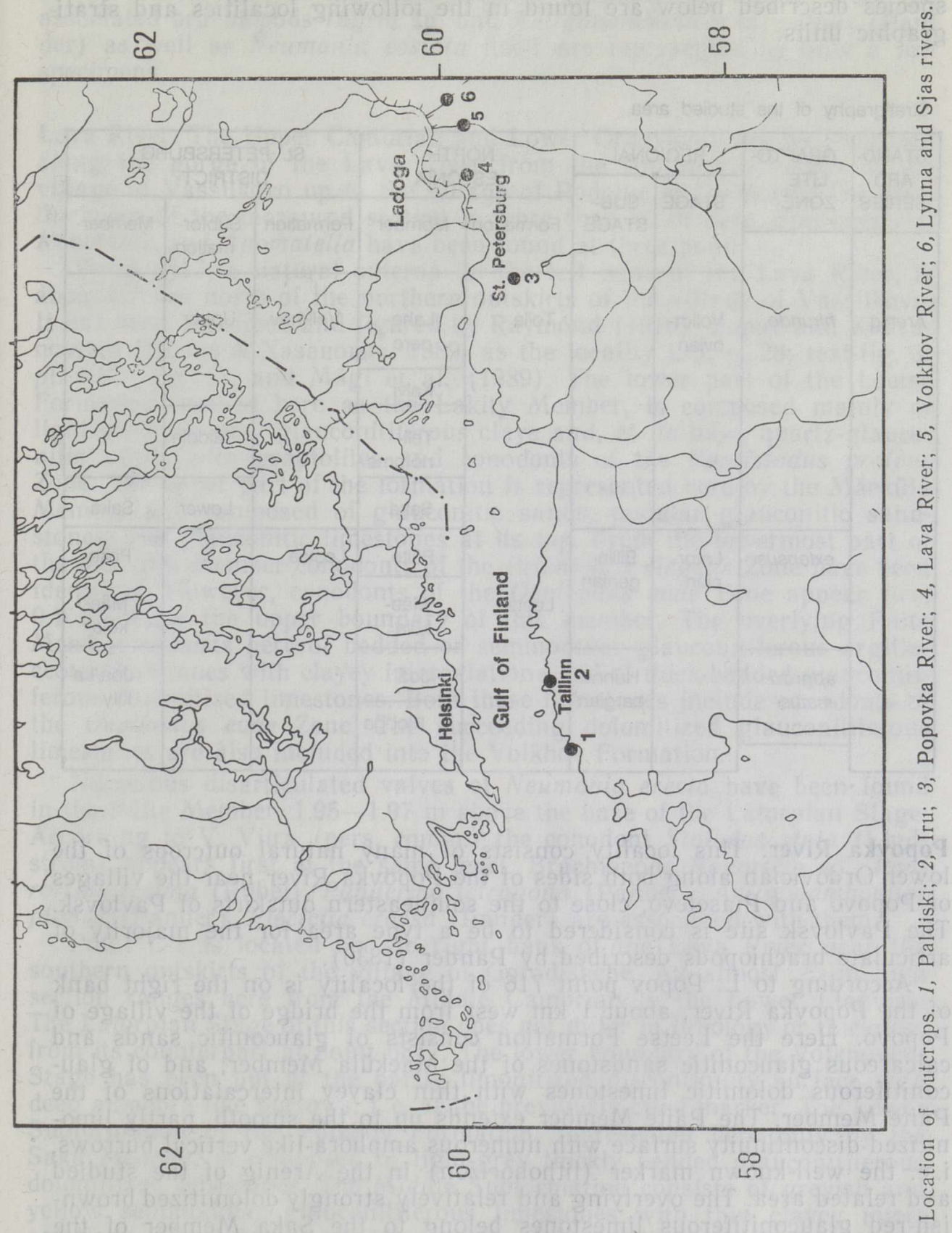




\section{GEOLOGIC SETTING AND DISTRIBUTION}

According to the regional stratigraphic scheme there are at least two Arenigian stages, the Latorpian and Volkhovian, in the East-European Platform (Männil \& Meidla, 1994). Along the Baltic klint these stages are represented by numerous members of three formations (Table). The species described below are found in the following localities and stratigraphic units.

Stratigraphy of the studied area

\begin{tabular}{|c|c|c|c|c|c|c|c|c|}
\hline \multirow{2}{*}{$\begin{array}{l}\text { STAND- } \\
\text { ARD } \\
\text { SERIES }\end{array}$} & \multirow{2}{*}{$\begin{array}{l}\text { GRAPTO- } \\
\text { LITE } \\
\text { ZONE }\end{array}$} & \multicolumn{2}{|c|}{ REGIONAL } & \multicolumn{2}{|c|}{$\begin{array}{l}\text { NORTH } \\
\text { ESTOR!A }\end{array}$} & \multicolumn{3}{|c|}{$\begin{array}{l}\text { St. PETERSBURG } \\
\text { DISTRICT }\end{array}$} \\
\hline & & \multirow[t]{2}{*}{ STAGE } & \multirow{2}{*}{$\begin{array}{l}\text { SUB- } \\
\text { STAGE }\end{array}$} & Formation & Member & Formation & Subfor- & Member \\
\hline \multirow{9}{*}{ Arenig } & \multirow{5}{*}{ hirundo } & & & & & & mation & \\
\hline & & \multirow[t]{4}{*}{$\begin{array}{l}\text { Volkh- } \\
\text { ovian }\end{array}$} & & \multirow[t]{4}{*}{ Toila } & $\begin{array}{l}\text { Lahe- } \\
\text { pere }\end{array}$ & \multirow[t]{4}{*}{ Volkhov } & Upper & \\
\hline & & & & & Kalvi & & & \\
\hline & & & & & $\begin{array}{l}\text { Teli- } \\
\text { nõmme }\end{array}$ & & Middle & \\
\hline & & & & & Saka & & Lower & Saka \\
\hline & \multirow[t]{2}{*}{ extensus } & \multirow{4}{*}{$\begin{array}{l}\text { Lator- } \\
\text { pian }\end{array}$} & \multirow{2}{*}{$\begin{array}{l}\text { Billin- } \\
\text { genian }\end{array}$} & \multirow{4}{*}{ Leetse } & Päite & \multirow[t]{4}{*}{ Leetse } & & \multirow[b]{2}{*}{$\begin{array}{l}\text { Mäe- } \\
\text { küla }\end{array}$} \\
\hline & & & & & $\begin{array}{l}\text { Mäe- } \\
\text { küla }\end{array}$ & & & \\
\hline & \multirow[t]{2}{*}{$\begin{array}{l}\text { approxi- } \\
\text { matus }\end{array}$} & & \multirow[t]{2}{*}{$\begin{array}{c}\text { Hunne- } \\
\text { bergian }\end{array}$} & & Joa & & & \multirow[t]{2}{*}{$\begin{array}{l}\text { Joa'La- } \\
\text { kity }\end{array}$} \\
\hline & & & & & & & & \\
\hline
\end{tabular}

Popovka River. This locality consists of many natural outcrops of the lower Ordovician along both sides of the Popovka River near the villages of Popovo and Piaselevo, close to the southeastern outskirts of Pavlovsk. The Pavlovsk site is considered to be a type area for the majority of articulate brachiopods described by Pander (1830).

According to L. Popov point 716 of the locality is on the right bank of the Popovka River, about $1 \mathrm{~km}$ west from the bridge of the village of Popovo. Here the Leetse Formation consists of glauconitic sands and calcareous glauconitic sandstones of the Mäeküla Member, and of glauconitiferous dolomitic limestones with thin clayey intercalations of the Päite Member. The Päite Member extends up to the smooth, partly limonitized discontinuity surface with numerous amphora-like vertical burrows, i. e. the well-known marker (lithohorizon) in the Arenig of the studied and related area. The overlying and relatively strongly dolomitized brownish-red glauconitiferous limestones belong to the Saka Member of the Volkhov Formation. The latter is well exposed along the left bank of the Popovka River in point 719.

The earliest Atelelasmatinae occurs at point 716, where Neumania erecta appears frequently $0.59-0.63 \mathrm{~m}$ above the base of the Latorpian Stage (sample No. 716/4) in the purple and light green clay of the Päite 
Member along with the following brachiopods: Panderina tetragona (Pander), Rānorthis sp., Paurorthis resima (Rubel), Plectella crassa (Pander). Associated taxa are the conodonts Oepikodus evae Lindström and Oistodus lanceolatus Pander as well as ostracodes and echinoderms.

The next species studied, Neumania costata (Pander), has been found in the middle part of the Saka Member (sample No. 719/9). Here the associated brachiopods Ingria sp. and Antigonambonites cf. planus (Pander) as well as Neumania costata itself are represented by only a few specimens.

Lava River. The Upper Cambrian and Lower Ordovician are well exposed along the gorge of the Lava River from the southern outskirts of the village of Vassilkovo up to the village of Podolye in the north. The total thickness of the measured section is more than $20 \mathrm{~m}$ here. Specimens of Neumania and Apomatella have been found at three points.

Point 6817 , a natural outcrop on the left bank of the Lava River, is about $0.3 \mathrm{~km}$ north of the northern outskirts of the village of Vassilkovo. It has been described and figured by Raymond (1916), Popov and Khazanovitch (Попов \& Хазанович, 1989; as the locality L-5: p. 28; text-fig. 3; pl. XIII, fig. 1), and Mägi et al. (1989). The lower part of the Leetse Formation, named here as the Lakity Member, is composed mainly of light greenish grey glauconitiferous clays and, at its base, quartz-glauconitic sands with graptolites and conodonts of the Paroistodus proteus Zone. The upper part of the formation is represented here by the Mäeküla Member and composed of glauconitic sands, nodular glauconitic sandstones, and glauconitic limestones at its top. From the lowermost part of the Mäeküla Member conodonts of the Prioniodus elegans Zone have been identified. However, conodonts of the Oepikodus evae Zone appear first $0.1 \mathrm{~m}$ below the upper boundary of this member. The overlying Päite Member consists here of bedded or seminodular glauconitiferous argillaceous limestones with clayey intercalations and of thick-bedded glauconitiferous dolomitized limestones. Both these limestones include conodonts of the Oepikodus evae Zone. The succeeding dolomitized glauconitiferous limestones are also included into the Volkhov Formation.

Numerous disarticulated valves of Neumania erecta have been found in the Päite Member, 1.95-1.97 $\mathrm{m}$ above the base of the Latorpian Stage. According to V. Viira (pers. comm.) the conodont Stolodus stola (Lindström) appears first at the same level. Brachiopods Ranorthis sp., Paurorthis resima (Rubel), Panderina tetragona (Pander), Antigonambonites planus (Pander), Plectella crassa (Pander) are associated with them.

Point L-1 is located on the right bank of the Lava River near the southern outskirts of the village of Gorodishche. An almost $25 \mathrm{~m}$ high section ranges here from the Middle Cambrian to the Lower Llanvirn. The Latorpian Stage of this section does not differ in lithology or thickness from its counterpart at point 6817. The lower boundary of the Volkhovian Stage has been put at the partly limonitized discontinuity surface with deep amphora-like burrows, i. e. at the previously cited marker. The Lower Subformation of the Volkhov Formation, represented here only by the Saka Member, is composed of light-grey thickly bedded glauconitiferous dolomitized limestones. The Middle Subformation consists of greyish and yellow seminodular glauconitiferous limestones with thin clayey intercalations. The light-grey nodular glauconitiferous limestones with numerous clayey intercalations as well as the greenish grey hard glauconitiferous limestones belong to the Upper Subformation. The discontinuity surface, $0.4 \mathrm{~m}$ below the base of the so-called lower oolitic bed (another lithohorizon in the studied area), has been regarded as the beginning of the Kundan Stage. 
There are two levels with species of the subfamily Atelelasmatinae in this section. The earlier one (sample No. L-1/11) with the species Neumania erecta in purple clays has exactly the same stratigraphic position as sample $6817 / 9$ from the corresponding point on the opposite bank of the river. The second level, with numerous disarticulated valves of the species Atelelasma secunda, corresponds to the top of the Volkhovian Stage and includes the following associated brachiopods: Productorthis obtusa (Pander), Paurorthis parva (Pander), Antigonambonites planus (Pander), and Ranorthis carinata Rubel.

The next point of the same outcrop, $729-7210$, is an old quarry on the left bank of the Lava River, opposite the village of Gorodishche. There are no differences in lithology or stratigraphy of the Volkhov Formation on either banks of the river. At this point the species Apomatella ingrica has been identified from the Middle Subformation, while Apomatella secunda occurs near the top of the Volkhov Formation at the same stratigraphic position as the previous point.

Volkhov River. In the natural outcrop of the right bank of the Volkhov River near the southern part of the village of Obukhovo denoted as point 755 , the late Tremadoc rocks as well as the Hunnebergian Substage are missing, and glauconitic sands and sandstones of the Mäeküla Member overlie the early Tremadocian kerogenous argillites. The Päite Member, overlying the Mäeküla Member, consists of greenish grey glauconitic limestones with clayey intercalations in its lower part and thick light-grey dolomitized glauconitic limestones in its upper part. There occurs, once again, the discontinuity surface with numerous amphora-like burrows, at which the Volkhovian Stage commences. At this point the latter stage is represented only by dolomitized glauconitiferous limestones of the Saka Member.

Neumania erecta has been again found only from the thin layer of the purple glauconitic clays of the Päite Member. Associated with it are the brachiopods Panderina tetragona (Pander), Ranorthis sp., Paurorthis resima (Rubel), Antigonambonites planus (Pander), and Plectella crassa (Pander), all from sample $755 / 4$.

\section{PLATE I}

Figs. 1-3, 6-10, 16. Apomatella ingrica. 1, 2-interior and exterior of dorsal valve $\mathrm{Br}$ 919; Sjas River. 3-interior of dorsal valve $\mathrm{Br}$ 964; Lava River. 6-10-lateral, dorsal, ventral, posterior, and anterior views of shell $\mathrm{Br}$ 967; Kolchanovo Quarry. 16interior of ventral valve $\mathrm{Br}$ 917; Lynna River. All from Volkhovian Stage. Coll. R. Männil and L. Hints, 1962.

Figs. 4, 5, 11-13. Apomatella secunda. 4, 5-exterior and interior of ventral valve $\mathrm{Br}$ 978; Lava River. Coll. L. Popov, 1989. 11-latex reprint from cast of ventral valve PMO 61097, Paleontological Museum of Oslo, holotype, Krekling, Norway. Expansusschiefer, Norway. Coll. A. Öpik, 1932. 12, 13-exterior and interior of dorsal valve Br 976; Lava River. Coll. L. Popov, 1989. All except for fig. 11 from the topmost part of Volkhovian Stage. Coll. L. Popov, 1989.

Figs. 14, 15. Neumania costata, interior and exterior of dorsal valve $\mathrm{Br} 913$; Iru, Estonia. Volkhovian Stage. Coll. K. Orviku, 1928.

Fig. 17. Neumania erecta, interior of the broken ventral valve $\mathrm{Br} 970$; Lava River. Latorpian Stage, Päite Member. Coll. L. Popov, 1975.

All figured specimens $\times 4.5$. 
PLATE I
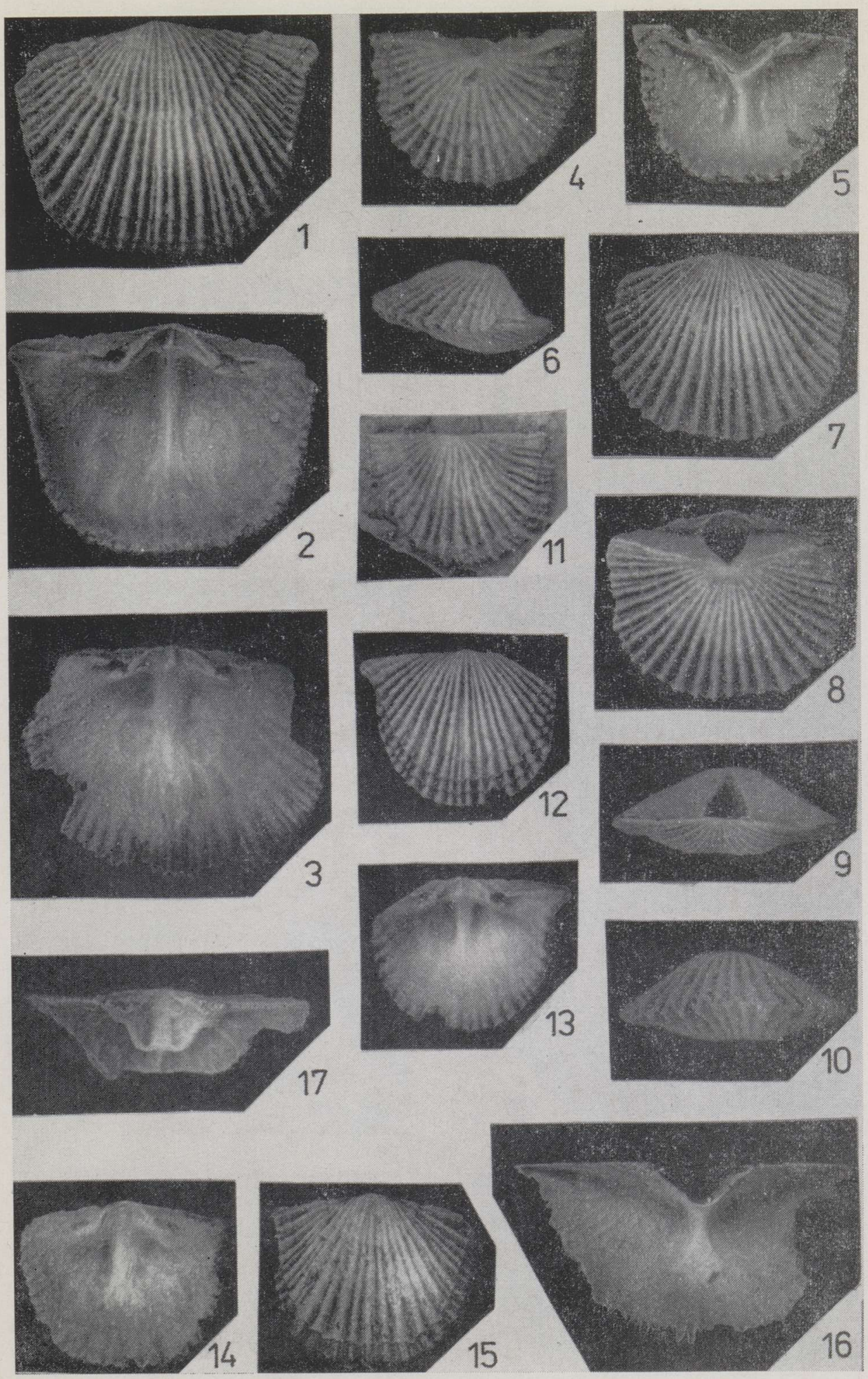
PLATE II
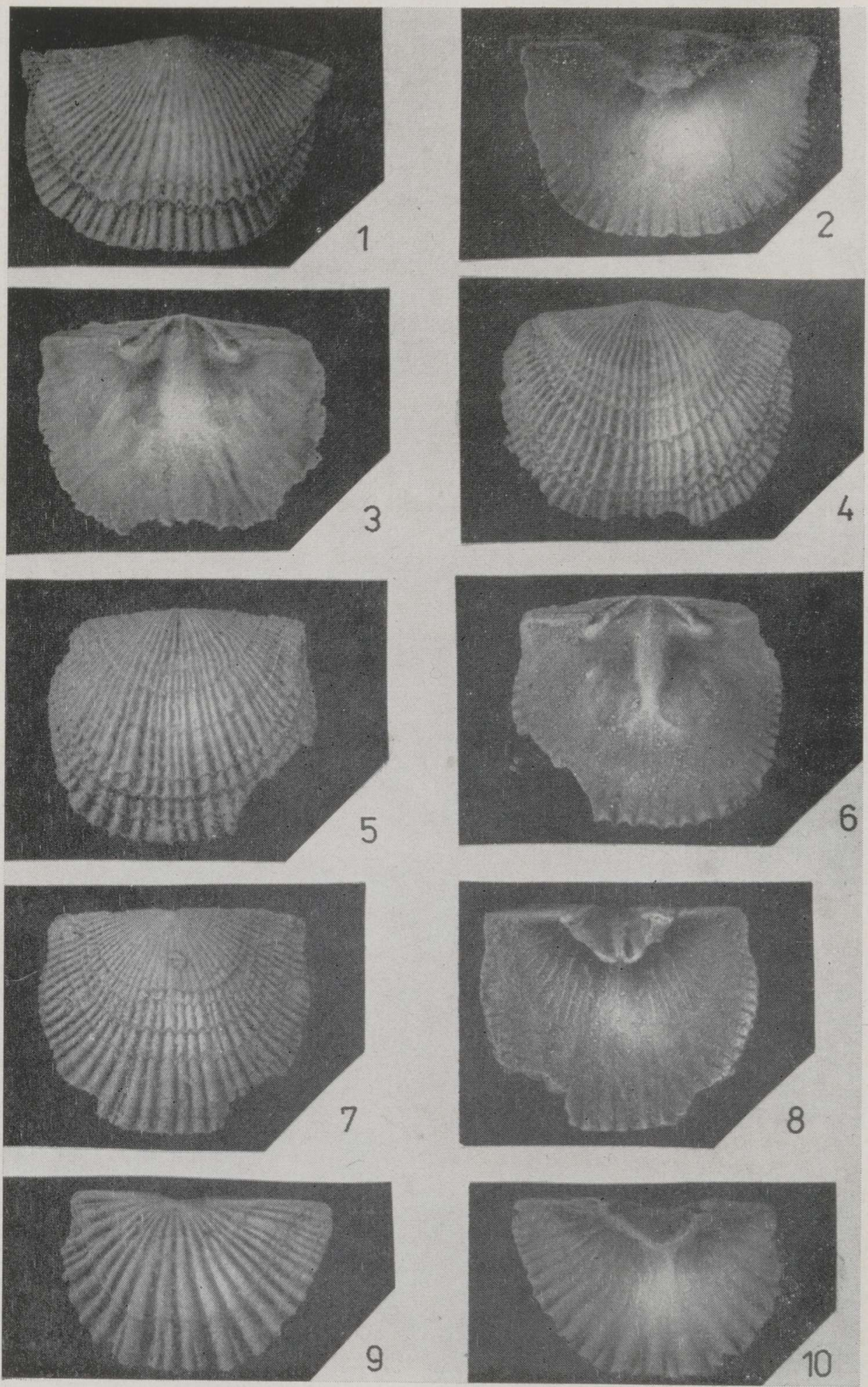


\section{SYSTEMATIC DESCRIPTIONS}

Family Clitambonitidae Winchell and Schuchert, 1893

Subfamily Atelelasmatinae Cooper, 1956

Genus Apomatella Schuchert et Cooper, 1931

Type species. Orthisina ingrica Pahlen, 1877, p. 48.

Diagnosis. Small-sized, ventribiconvex atelelasmatine; ventral interarea procline; external ornamentation of equal ribs, crossed by fila; ventral adductor scars equal in length to diductor scars or longer than diductor scars; pedicle callist absent; notohyrium flanked by chilidial plates.

Apomatella ingrica (Pahlen, 1877)

Pl. I, figs. $1-3,6-10,16$

Orthisina ingrica Pahlen, 1877, p. 48, pl. 2, figs. 18-20; non pl. 2, fig. 21.

Apomatella ingrica; Öpik, 1934, p. 128, pl. 3, figs. 6, 7; non Öpik, 1939, p. 131, pl. 2, fig. 10 .

Description. Shell length up to $7.1 \mathrm{~mm}$ and maximum width $9.6 \mathrm{~mm}$; ventribiconvex. Outline subtrapezoidal. Maximum width of shell at hinge line. Cardinal extremities slightly acute to acute. Sides straight. Anterior margin straight. Anterior commissure slightly sulcate to rectimarginate. Surface costellate. Ribs numbering 3-4 per $\mathrm{mm}$ at anterolateral margin. Ribs increasing in number by splitting in all parts of valve surface; angular; mostly of unequal size. Ribs crossed by filae (very thin).

Ventral valve high; symmetrical; medianly flattened. Highest point of valve at apex, or slightly anterior to apex. Flanks flat. Interarea height 0.4 of width; convex to planar; procline; with faint striae parallel to hinge. Delthyrium height 1.4 of width; bordered laterally by lateral plates. Hinge teeth small; plate-like; nearly parallel to interarea. Dental plates well-developed; forming spondylium simplex. Anterior edge of spondylium extends anteriorly beyond hinge line; elevated; supported totally by septum and secondary shell material. Floor of spondylium not clearly distinguished. Muscle scars not clearly developed. Diductor scars anteriorly straight; shorter than adductor scars. Pedicle callist not developed. Supporting ridge as long as spondylium. Interior surface smooth. Subperipheral rim not developed.

\section{PLATE II}

Figs. 1, 2. Neumania costata, exterior and interior of ventral valve $\mathrm{Br} 980$; Popovka River, lowermost part of Volkhovian Stage. Coll. V. Lamansky.

Figs. 3-8. Neumania erecta. 3, 4-interior and exterior of dorsal valve $\mathrm{Br} 972$; Lava River. 5, 6-exterior and interior of dorsal valve $\mathrm{Br} 970$; Lava River. 7, 8 -exterior and interior of ventral valve $\mathrm{Br}$ 968; Popovka River. All from Päite Member of Latorpian Stage. Coll. L. Popov, 1975.

Figs. 9, 10. Apomatella secunda, exterior and interior of ventral valve $\mathrm{Br} 974$; Lava River, upper member of Volkhovian Stage. Coll. L. Popov.

All figured specimens $\times 4.5$. 
Dorsal valve convex; beak erect; with median sulcus; beginning from umbo and developed in anterior half of valve. Flanks bounding sulcus swollen. Cardinal extremities depressed. Interarea narrow; flat; orthocline. Notothyrium partly closed by two chilidial plates. Cardinal process developed; in form of lanceolate plate. Notothyrial platform nearly flush with dorsal interarea; well developed and sharp. Dental sockets small; with anterior thickening, parallel to hinge line. Median ridge as long as adductor field; rounded. Adductor field obscure. Anterior pair of adductor scars greater than posterior pair. Interior surface smooth. Subperipheral rim weakly developed; in form of knobs. Vascular marking not developed.

Shell substance impunctate.

Discussion. The species differs from the closest species Apomatella secunda Öpik, 1939, in more procline ventral interarea as well as a pair of stronger costellae bounding the flattened and sulcate median sectors of ventral and dorsal valves respectively.

Distribution. The Volkhovian Stage, Arenig, St. Petersburg District, Russia, and North Estonia.

Material. More than 50 specimens.

Apomatella secunda Opik, 1939

Pl. I, figs. $4-5,11-13$

Apomatella secunda Öpik, 1939, p. 131, pl. 2, figs. 11, 12.

Apomatella ingrica; Öpik, 1939, p. 131, pl. 2, fig. 10.

? Orthisina ingrica var.; Pahlen, 1877, p. 50, pl. 2, figs. 18-20.

Types: Holotype-ventral valve No. 61097 of Paleontological Museum of Oslo selected by Opik, 1939, p. 131.

Description. Shell length up to $6.0 \mathrm{~mm}$ and maximum width $9.3 \mathrm{~mm}$; ventribiconvex. Outline subtrapezoidal. Maximum width of shell at hinge line. Cardinal extremities acute to alate. Sides straight to concave. Anterior margin slightly rounded. Anterior commissure slightly sulcate to rectimarginate. Surface costellate. Ribs numbering $2-4$ per $\mathrm{mm}$ at anterolateral margin. Ribs increasing in number by splitting on all parts of valve surface; rounded or angular; of equal size. Ribs crossed by filae (very thin).

Ventral valve high; symmetrical; medianly flattened. Highest point of valve slightly anterior to apex. Flanks concave in posterolateral area. Interarea height 0.3 of width; convex or planar; nearly catacline; with faint striae parallel to hinge. Delthyrium as high as wide; open. Hinge teeth small; as simple extensions. Dental plates well-developed; forming spondylium simplex. Anterior edge of spondylium extends anteriorly as far as hinge line; elevated; supported totally by septum and secondary shell material. Floor of spondylium not clearly distinguished. Muscle scars not developed. Pedicle callist not developed. Supporting ridge longer than spondylium. Interior surface smooth. Subperipheral rim developed; in form of knobs.

Dorsal valve convex; beak erect; with median sulcus; developed in anterior half of valve and disappearing in anterior half of valve. Flanks bounding sulcus swollen. Cardinal extremities slightly concave. Interarea narrow; flat; orthocline. Notothyrium partly closed by two chilidial plates. Cardinal process weakly developed; as low ridge. Notothyrial platform nearly flush with dorsal interarea; well developed; anteriorly merging 
into median ridge. Dental sockets small; simple. Median ridge as long as adductor field; angular. Adductor field slightly impressed. Anterior pair of adductor scars bigger than posterior pair; ridge between transverse. Posterior adductor scars circular in outline. Anterior adductor scars simple. Interior surface smooth. Subperipheral rim weakly developed; in form of knobs. Vascular marking developed.

Shell substance impunctate.

Discussion. The mostly catacline ventral interareas, well-developed ventral and dorsal septa, as well as the equal size of radial ribs (costae) characterize the described species and distinguish it from the species Apomatella ingrica (Pahlen). The alate state of cardinal extremities is much more distributed among specimens of $A$. secunda than among $A$. ingrica. Because of these characters as well as the clear ventral supporting septum in the specimens described by Öpik as $A$. ingrica from the Expansusschiefer of Norway (see synonymy), it is reasonable to consider them conspecific with $A$. secunda. The differences noted by A. Pahlen for his variety (see synonymy) are probably sufficient to consider that form also conspecific with the described species.

Distribution. Topmost part of the Volkhovian Stage, Arenig, St. Petersburg District, Russia, and the Expansusschiefer, Arenig, Norway.

Material. Nine ventral and two dorsal valves.

Genus Neumania Harper, 1981

Type species. Atelelasma atlanticum Neuman, 1976, p. 24.

Diagnosis. Medium-sized, ventribiconvex atelelasmatine; ventral interarea procline to apsacline; external ornamentation of equal ribs, covered by imbrication; ventral adductor scars shorter than diductor scars; pedicle callist present; notothyrium covered with chilidium or flanked by chilidial plates.

Neumania erecta (Pander, 1830)

Pl. I, fig. 17 ; pl. II, figs. $3-8$

Gonambonites erecta Pander, 1830, p. 79, pl. 16B, fig. 10.

Description. Shell length up to $8.2 \mathrm{~mm}$ and maximum width $9.5 \mathrm{~mm}$; ventribiconvex. Outline subtrapezoidal to subquadrate. Maximum width of shell at hinge line. Cardinal extremities right-angled to acute. Sides convex to straight. Anterior margin emarginate to straight. Anterior commissure slightly sulcate. Surface costellate. Ribs numbering $4-6$ per $2 \mathrm{~mm}$ at $5 \mathrm{~mm}$ from ventral beak. Ribs increasing in number by intercalation in median region and at cardinal extremities; rounded to angular; of equal size. Ribs covered with growth lamellae; imbricated irregularly.

Ventral valve high; symmetrical; subcarinate (posteriorly) and medianly flattened (anteriorly). Highest point of valve slightly anterior to apex. Flanks flat. Interarea height 0.4 of width; planar to concave; procline to apsacline; with faint striae parallel to hinge. Delthyrium height $1.1-1.3$ of width; bordered laterally by lateral plates. Hinge teeth small; as simple extensions. Dental plates well-developed; forming spondylium simplex. Anterior edge of spondylium extends anteriorly beyond hinge line; elevated; supported totally by septum and secondary shell material. Floor of spondylium flattened. Muscle scars impressed. Adductor scars anteriorly 
straight; width $0.3-0.5$ of floor width. Diductor scars anteriorly rounded; extending anterior to adductor scars. Pedicle callist present; length $0.3-$ 0.5 of spondylium length. Supporting ridge shorter than spondylium. Interior surface smooth. Subperipheral rim developed in form of furrows and knobs.

Dorsal valve convex; beak erect; with median sulcus; beginning from umbo and developed in anterior half of valve. Flanks bounding sulcus swollen. Cardinal extremities depressed to convex. Interarea narrow; flat to concave; orthocline. Notothyrium partly covered by chilidial plates. Cardinal process weakly developed; as low ridge. Notothyrial platform nearly flush with dorsal interarea; weakly developed; anteriorly merging into median ridge. Median ridge as long as adductor field; rounded. Adductor field impressed. Anterior pair of adductor scars greater than posterior pair; ridge between transverse. Posterior adductor scars circular in outline. Anterior adductor scars simple. Interior surface smooth. Subperipheral rim weakly developed; in form of furrows. Vascular marking slightly developed.

Shell substance impunctate.

Discussion. All characters of the described specimens, especially the iligh and subcarinate ventral valve with open delthyrium as well as fine external ornamentation, are considered to be conspecific with the species Gonambonites erecta figured and briefly described by Pander (see synonymy). This species differs from other species of the genus in a weakly developed imbrication and in a deeply impressed ventral muscle scars on the floor of the spondylium.

Distribution. The Päite Member of the Latorpian Stage, Arenig, St. Petersburg District, Russia.

Material. 22 dorsal valves and 21 ventral valves.

Neumania costata (Pander, 1830)

Pl. I, figs. 14,$15 ;$ pl. II, figs. $1,2,9,10$

Pronites costata Pander, 1830, p. 73, pl. 24 , fig. 8 .

Pronites marginata Pander, 1830, p. 73, pl. 26, fig. 15.

Description. Shell length up to $6.4 \mathrm{~mm}$ and maximum width $8.5 \mathrm{~mm}$; ventribiconvex. Outline subtrapezoidal. Maximum width of shell at hinge line. Cardinal extremities acute. Sides straight. Anterior margin straight. Anterior commissure slightly sulcate. Surface costate to costellate. Ribs numbering 2-4 per $\mathrm{mm}$ at the anterolateral margin. Ribs increasing in number by splitting; on all parts of valve surface; angular; of equal size. Ribs crossed by growth lines.

Ventral valve high; symmetrical; subcarinate. Highest point of valve slightly anterior to apex. Flanks flat. Interarea height 0.4 of width; planar; procline to catacline; with faint striae parallel to hinge. Delthyrium height 1.2 of width; open. Dental plates well-developed; forming spondylium simplex. Anterior edge of spondylium extends anteriorly beyond hinge line; elevated; supported totally by septum and secondary shell material. Floor of spondylium flattened. Muscle scars impressed. Adductor scars anteriorly straight; width 0.5 of spondylial floor. Diductor scars anteriorly rounded; extending anterior to adductor scars. Pedicle callist present; length 0.4 of spondylium length. Supporting ridge slightly longer than spondylium. Interior surface smooth. Subperipheral rim developed; in form of knobs. 
Dorsal valve convex; beak erect; with median sulcus; beginning from umbo and developed in anterior half of valve. Flanks bounding sulcus swollen. Cardinal extremities depressed. Interarea narrow; flat; orthocline. Notothyrium partly closed by two chilidial plates. Cardinal process weakly developed, or lacking. Notothyrial platform nearly flush with dorsal interarea; weakly developed; anteriorly merging into median ridge. Dental sockets small; with anterior thickening, parallel to hinge line. Median ridge as long as adductor field; rounded. Adductor field obscure. Anterior pair of adductor scars greater than posterior pair. Interior surface smooth. Subperipheral rim weakly developed.

Shell substance impunctate.

Discussion. The described specimens have a spondylium similar to the previously described species, which is, in turn, taken as diagnostic for the genus. The Apomatella-like (subpyramidal) shell and the costate state of radial ribs are quite unique characters for the brachiopods of the area as well as the stratigraphic interval studied for Pander's names (species) to be used for the described specimens. It is noteworthy that according to the rare copy of Pander's book with coloured (handmade) plates kept in the State Museum of Stockholm the red colour of Pander's figures of the synonymized species suggests a similar stratigraphic position, which supports the supposed conspecificity.

Distribution. The Saka Member of the Volkhovian Stage, Arenig, St. Petersburg District, Russia, and North-West Estonia (Paldiski and Iru localities).

Material. 1 shell, 2 ventral and 1 dorsal valves.

\section{ACKNOWLEDGEMENTS}

We gratefully acknowledge A. D. Wright (Queen's University, Belfast) for his critical reading of the manuscript. Photos were made by Erik Grünberg (Institute of Geology, Tallinn).

\section{REFERENCES}

Bruton, D., Harper, D. A. T. 1981. Brachiopods and trilobites of the early Ordovician serpentine Otta Conglomerate, south central Norway. - Norsk Geologisk Tidsskrift, 61, 155-181.

Mägi, S., Viira, V., Aru, H. 1989. On the correlation of the Tremadocian and Arenigian boundary beds in the East Baltic. - Proc. Estonian Acad. Sci. Geol., 1989, $38,2,63-67$.

Männil, R. and Meidla, T. 1994. A. The Ordovician System of the East European Platform (Estonia, Latvia, Lithuania, Byelorussia, parts of Russia, the Ukraine and Moldova). - In: Webby, B. D., Ross, R. J., Jr., Zhen, Y. Y. (eds.). The Ordovician System of the East European Platform and Tuva (southeastern Russia). International Union of Geological Sciences Publication No. 28, 1-52.

Neuman, R. B. 1976. Early Ordovician (late Arenig) brachiopods from Virgin Arm, New World Island, Newioundland. - Geol. Survey Canada Bull. 261, 11-61.

Opik, A. 1934. Ober Klitamboniten. - Acta et Commentationes Universitatis Tartu, A, $17,1,1-262$.

Opik, A. 1939. Brachiopoden und Ostrakoden aus dem Expansusschiefẹ Norwegens. Norsk Geologisk Tidsskrift, 19, 117-142. 
Pahlen, A. von. 1877. Monographie der Baltisch-Silurischen Arten der BrachiopodenGattung Orthisina. - Mémoires de l'Académie Impériale des Sciences de St. Pétersbourg, VIIe série, 24, 8, 1-52.

Pander, C. 1830. Beiträge zur Geognosie des Russischen Reiches. St. Petersburg.

Raymond, P. E. 1916. The correlation of the Ordovician strata of the Baltic Basin with those of Eastern North America. - In: Raymond, P., Twenhofel, W. Expedition to the Baltic Provinces of Russia and Scandinavia, 1914. Bulletin of Museum of Comparative Zoology at Harvard College, 56, 3, 79-286.

Попов Л., Хазанович К. 1989. Лингулаты (беззамковые брахиоподы с фосфатнокальцитовой раковиной). - In: Опорные разрезы и стратиграфия кемброордовикской оболовой толщи на северо-западе Русской платформы. Наука, Ленинград, 96-136.

\title{
BALTI KLINDIALA ORDOVIITSIUMI \\ BRAHHIOPOODID SUGUKONNAST ATELELASMATINAE (CLITAMBONITACEA)
}

\author{
Madis RUBEL, Leonid POPOV
}

Uute leidude põhjal on kirjeldatud nelja siiani halvasti tuntud liiki perekondadest Apomatella ja Neumania ning revideeritud mõlema perekonna diagnoosi.

\section{БРАХИОПОДЫ ПОДСЕМЕЙТВА ATELELASMATINAE (СLITAМВONITACEA) ИЗ АРЕНИГА (ОРДОВИКА) БАЛТИИСКОГО ГЛИНТА}

\author{
Мадис РУБЕЛЬ, Леонид ПОПОВ
}

На основе новых коллекций брахиопод из региона балтийского глинта дано описание и дополнены диагнозы четырех, до сих пор малоизвестных видов наиболее древних родов клитамбонитидных брахиопод - Apomatella и Neumania. 